\title{
EFFECT OF FREEZING AND SALTING ON THE ACTIVITY OF LIPOXY GENASE OF THE MUSCLE TISSUE AND ROE OF BALTIC HERRING
}

\section{WPLYW ZAMRAZZANIA ORAZ SOLENIA NA AKTYWNOŚĆ LIPOOKSYGENAZY TKANKI MIĘŚNIOWEJ I IKRY ŚLEDZI BAETYCKICH}

\author{
Department of Refrigeration, Agricultural University of Szczecin, Poland
}

Freezing followed by frozen storage of Baltic herring at $-25^{\circ} \mathrm{C}$ for a period of 6 months resulted in lowering the activity of lipoxygenase of the muscle tissue down to $78.2 \%$ and of the roe--down to $70.0 \%$. The activity of the enzyme, extracted from the muscle tissue, stored in a buffer solution at $-10,-18$, and $-25^{\circ} \mathrm{C}$ declined in reverse proportion to the increase of the storage temperature.

Salting of herring, until they reached from 9.8 to $18.5 \%$ of salt content in their muscle tissue caused a decline in the activity of lipoxygenase, which was in direct proportion to the concentration of salt. Lipoxygenase of roe was catalysed more extensively during the weak salting $(9.8 \% \mathrm{NaCl})$ than it was during medium- $(12.3 \% \mathrm{NaCl})$ or strong salting $(18.3 \%$ $\mathrm{NaCl})$.

\section{INTRODUCTION}

Lipoxygenase is responsible for catalysing cis, cis-1, 4-pentadiene sequences through separation of a hydrogen atom from active methylene groups of polyunsaturated fatty acids. The result of this reaction is alkyl radical, which is capable of creating-with molecular oxygen — hydroperoxides with trans, cis—-linked with a double bond (Gardner 1980; German and Kinsela 1985, 1986; German et al. 1986; Mohri et al. 1990; Hultin 1992, 1994; Hsu and Pan 1996). Hydroperoxides are unstable and they can break apart through haemolytic disintegration or through $\beta$-splitting providing such fragmentation products as: aldehydes, ketones, alcohols, epoxides, hydroxyketones, esters and others. According to Yamamoto (1992) they can be formed also in the presence of lipoxygenase, which is capable of breaking apart $\mathrm{C}-\mathrm{C}$ bonds and creating hydroxyl groups. 
In previous studies, the presence of lipoxygenase was stated in the muscle tissue of fishes (McDonald et al. 1979; Apgar and Hultin 1982; Hultin et al. 1982; German and Kinsela 1986; Takiguchi 1989; Wang et al. 1991; Harris and Tall 1994; Stodolnik and Samson 2000), fish gills (German and Kinsela 1986; Hsieh and Kinsela 1989; German and Hu 1990; Gell et al. 1995; Hsu and Pan 1996; Stodolnik and Samson 2000), fish skin (Andersen et al. 1981; German and Kinsela 1986; Wang et al. 1991; Mohri et al. 1992; Triqui and Reineccius 1995; Stodolnik and Samson 2000) and in the roe and milt (Stodolnik and Samson 2000).

Among fish lipoxygenases, the principal role is played by two isoenzymes: 12- and 15-lipoxygenase (Grun and Barbeau 1995). 12-lipoxygenases show specificity in relation to carbon of n-9 and n-12 polyunsaturated fatty acids $\mathrm{C}_{20}$ and $\mathrm{C}_{22}$. These acids after accepting molecular oxygen and after positional isomerisation transform into 12-hydroperoxides (German and Kinsella 1985; Winkler et al. 1991), which can be a source of eight- and ninecarbon aldehydes, ketones, and alcohols. 15-lipoxygenases prefer double bonds at the positions $\mathrm{n}-6$ and $\mathrm{n}-9$. The outcome of their action are 15-hydroperoxides, which take part in creation of compounds containing 5-6 atoms of carbon (Josephson and Lindsay 1986).

From the gills of mugil (Mugil cephalus) Hsu and Pan (1996) isolated three isoenzymes: 5-, 12-, 15-lipoxygenase. Among them 12-lipoxygenase turned out to be the most active enzyme. On the other hand, the activity of 15-lipoxygenase and 5-lipoxygenase constituted respectively $64 \%$ and $4 \%$ of the activity of 12 -lipoxygenase. Among enzymes present on the gills of rainbow trout, 12-lipoxygenase showed higher activity than 15-lipoxygenase (German and Kinsella 1986). On the other hand a dominant role of 15-lipoxygenase in the gills of the same fish species was visible in the studies of German and Creveling (1990).

The activity of fish lipoxygenases is a feature depending on a species. Stodolnik and Samson (2000) determined that this activity is also influenced by the stage of gonad maturity and the period of catches of Baltic herring. Important factors modifying activity of lipoxygenases are $\mathrm{pH}$ and temperature. For the majority of examined fish species, the optimal $\mathrm{pH}$ values for lipoxygenase activity are in the narrow range of 6 to 7 (Slabyj and Hultin 1982; Decker et al. 1988; Hultin 1988; Eun et al. 1992; Hsu and Pan 1996; Huang et al. 1998). The optimal temperature for this type of enzymes present in the fish raw materials ranges from 20 to $37^{\circ} \mathrm{C}$ (Apgar and Hultin 1982; Slabyj and Hultin 1982; McDonald and Hultin 1987; Hsieh et al. 1988; Eun et al. 1992). Within the range of freezing temperatures from -2 to $-22^{\circ} \mathrm{C}$ the activity of the lipid-oxidising enzymatic system of a flatfish was lowered along with the drop of temperature (Apgar and Hultin 1982), but at $-22^{\circ} \mathrm{C}$ was maintained still at a relatively high level. 
The activity of lipoxygenase isolated from the skin of Plecoglossus altivelis, after 2-week storage at $-50^{\circ} \mathrm{C}$ rapidly declined down to $60 \%$ of the initial value and remained at this level during further 80 -day storage. On the other hand, at $-80^{\circ} \mathrm{C}$, the activity of the enzyme declined to the level of $80 \%$ of the initial value and it did not change throughout the next 10 weeks (Zhang et al. 1992).

An important role in the activity of lipoxygenases of fishes is played by metal ions, which can be activators of an enzyme through its binding with a substrate or release of its active centre. Catalytic activity of iron ions and copper ions is known in the processes of enzymatic oxidation of lipids. Metal ions used in a form of $\mathrm{FeCl}_{3}$ and $\mathrm{CuSO}_{4}$ in the range of concentrations from 0 to $3.6 \mu \mathrm{M}$ showed much higher catalytic action of iron ions than copper ions (Decker et al. 1989). It was confirmed also by other studies (Decker and Hultin 1990; Mohri et al. 1992). Enzymatic oxidation of lipids is also influenced by $\mathrm{NaCl}$ content. Osinchak et al. (1992) demonstrated catalysing action of this compound in the concentration of $0.43 \mathrm{M}$ on lipoxygenase of the muscle tissue of a mackerel. According to Apgar and Hultin (1982) $\mathrm{NaCl}(0.15 \mathrm{M})$ is more effective catalyser of lipoxygenase of the muscle tissue of a flatfish than $\mathrm{KCl}(0.15 \mathrm{M})$.

Fish salting, particularly of clupeid fishes, in this number also Baltic herring has been a common method of their preservation. This technology involves usage of a salt, with sodium chloride as a dominant component. Other supplementary salts may diversify the activity of lipoxygenases present in the fish raw materials. Fish processing is based on both fresh and frozen raw materials. Because the quality of Baltic herring stored under frozen conditions is in high degree limited by oxidative transformations of lipids, it is possible that these transformations are also of enzymatic nature. The hitherto conducted studies provided no information on the effect of frozen storage and salting of Baltic herring on the activity of enzymatic oxidation of lipids. In view of the above the present study was initiated, aimed on determining the importance of lipoxygenase activity in such raw material and under above-described technological processes.

\section{MATERIAL AND METHODS}

\section{Material}

The present study was based on Baltic herring caught on fishing ground in the area of Kołobrzeg in May 1997, as well as February 1998 and 1999. The fish were at $4^{\text {th }}$ and $5^{\text {th }}$ stage of gonad maturity according to Maier. Herring were brought to a laboratory in a chilled (iced) state. Fish for the study were selected when the rigor mortis faded away. Assorted females were ended up in packages weighing ca $250 \mathrm{~g}$, wrapped in polyethylene foil and sealed using an electric sealer. Fish prepared in such way were frozen and kept at $-25^{\circ} \mathrm{C}$ for 24 weeks. On the other hand, fish for salting (females) were divided into 3 lots 
and were subjected to three experimental treatments: weak salting, medium salting and strong salting, within 4 weeks, at $4^{\circ} \mathrm{C}$. Salt doses of $12.5,17.5$, and $25.0 \mathrm{~kg}$, respectively were used for lots of $100 \mathrm{~kg}$ of fish.

To determine the effect of salt composition on the activity of lipoxygenase of the muscle tissue of Baltic herring a model study was carried out. The following compounds were used: $\mathrm{NaCl}(1.0-26.4 \%), \mathrm{CaCl}_{2}$ (0.5-5.0\%), $\mathrm{MgCl}_{2}(0.5-3.0 \%), \mathrm{KCl}(0.5-3.0 \%)$, and a mixture of sodium chloride with additions of the remaining salts ( $1.66 \%$ of each salt) of a joint concentration of 2.0 to $26.4 \%$.

Methods

Extraction of lipids from muscle tissue of analysed material of used as the substrate for determining the activity of lipoxygenase of Baltic herring was carried out a chloroform-methanol mixture (2:1) (Linko 1967). The solvents were distilled out under lowered pressure at the temperature not exceeding $40^{\circ} \mathrm{C}$.

Extracts of lipoxygenase in $10.0 \mathrm{mM}$ phosphate buffer ( $\mathrm{pH} 7.0)$ were prepared a modified method of Harris and Tall (1994) described in detail in the work of Stodolnik and Samson (2000).

Activity of lipoxygenase was determined using the modified methods of Slabyj and Hultin (1984) and Harris and Tall (1994)—described in detail in the work of Stodolnik and Samson (2000).

Malondialdehyde content determined through usage of 2-thiobarbituric acid according to the method of Schmedes and Hølmer (1989) and its concentrations were read from standardisation curve prepared for 1,1-3,3 tetraethoxypropane and the results were expressed in nmol $\mathrm{AM} / \mathrm{mg}$ of protein.

Determination of protein content in enzyme extracts were carried out spectrophotometrically under wave length of $280 \mathrm{~nm}$. Protein concentration was determined from a standardisation curve, prepared for beef albumin. The results were expressed in $\mathrm{mg} / \mathrm{cm}^{3}$.

Sodium chloride content in the muscle tissue and roe of Baltic herring was determined employing the method of Volhard.

\section{RESULTS}

Influence of the duration of frozen storage at $-25^{\circ} \mathrm{C}$ on the activity of lipoxygenase of the muscle tissue and roe of Baltic herring were determined based on fish caught in May 1997. The results obtained, indicate, that 2 -week storage of raw materials does not diminish activity of this enzyme (Fig. 1). On the other hand, a rapid lowering of the enzyme activity was observed after 4 weeks of storage. In the case of the muscle tissue it was 88.2 percentage points, while for roe- 49.6 percentage points. In the subsequent weeks, the lipoxygenase activity showed fluctuations, which had wider amplitude for the muscle tis- 
sue, than for the roe and the average enzyme activity was $69.5 \%$ and $64.9 \%$ respectively in storage period of the raw materials of 4 to 24 weeks. Analysing the entire period of frozen storage of Baltic herring, no statistically significant difference, between the activity of lipoxygenase of the muscle tissue and the roe were observed (Table 1). In general lipoxygenase of the muscle tissue and the roe of analysed fish was very stable during the period of half-year storage at $-25^{\circ} \mathrm{C}$. It retained in average 78.2 and $70.0 \%$ of the initial activity in unfreezing raw material, respectively.

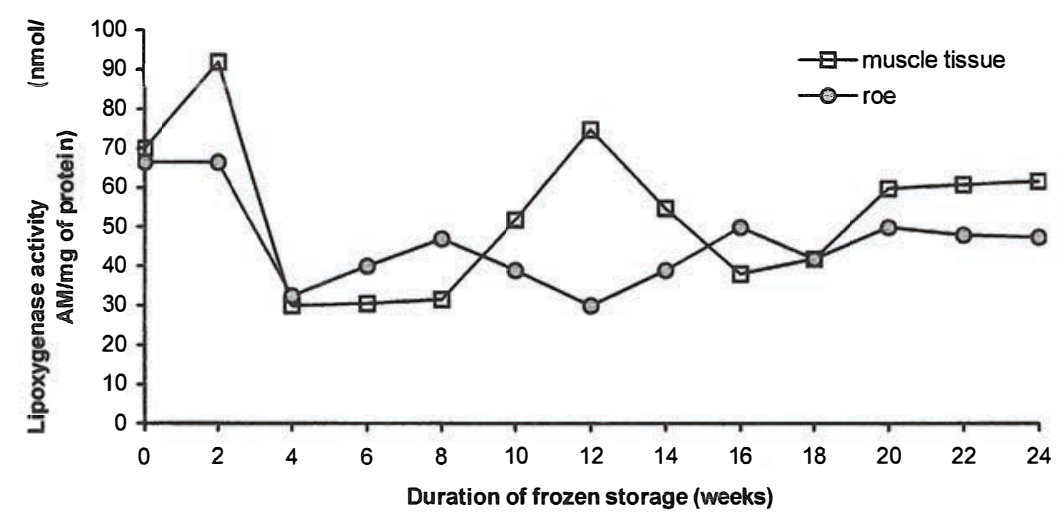

Fig. 1. Effect of the duration of frozen storage $\left(-25^{\circ} \mathrm{C}\right)$ on activity of lipoxygenase of the muscle tissue and roe of Baltic herring

Table 1

Student t-test values for lipoxygenase activity of the muscle tissue and roe of Baltic herring, stored under frozen condition (temperature of $-25^{\circ} \mathrm{C}$, time 24 weeks)

\begin{tabular}{|c|c|c|}
\hline \multirow{2}{*}{ Sample } & \multicolumn{2}{|c|}{ Roe } \\
\cline { 2 - 3 } & $\mathrm{t}$ & $\mathrm{p}$ \\
\hline Muscle tissue & 1.594 & 0.137 \\
\hline
\end{tabular}

$\mathrm{t}$, Student $\mathrm{t}$-test value

$\mathrm{p}$, significance level $(\alpha=0.05)$

To determine the effect of temperature $\left(-10,-18\right.$, and $\left.-25^{\circ} \mathrm{C}\right)$ on the lipoxygenase activity, a study was initiated on the enzyme extracted from the muscle tissue of herring caught in February 1998. A model system with a lipid substrate in a phosphate buffer (pH 7.0) was used. The results obtained, demonstrated that in these conditions, lipoxygenase was quickly inactivated, because after two weeks its activity declined down to 46.6$48.4 \%$ at $-10,-18$, and $-25^{\circ} \mathrm{C}$, respectively. In subsequent period of storage, the enzyme activity exhibited fluctuations, with a declining tendency (Fig. 2). The highest activity within 6-month storage period, lipoxygenase retained at $-25^{\circ} \mathrm{C}$, lower-at $-18^{\circ} \mathrm{C}$, while the lowest-at $-10^{\circ} \mathrm{C}$. The activities amounted to $35.4,30.9$, and $25.8 \%$, respectively, of the initial activity before the storage. Statistical analysis of the results, revealed differences in activity of enzyme, under the above-mentioned temperature regimes (Table 2). In general, 
lipoxygenase of the muscle tissue of Baltic herring was in lower extent inhibited at lower freezing temperatures. Ascertained also that lipoxygenase retains in lower degree its activity in the buffer solution, than in the environment of a natural muscle tissue. It is possible that components of this tissue protect the enzyme under freezing conditions.

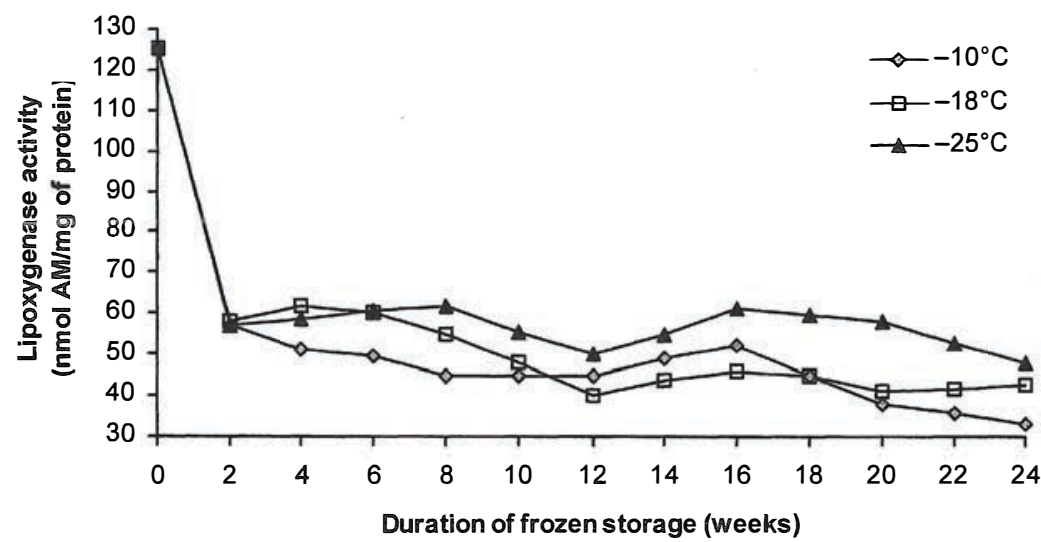

Fig. 2. Effect of the temperature of frozen storage on the activity of lipoxygenase of the muscle tissue of Baltic herring

Table 2

Student t-test values for lipoxygenase activity of the muscle tissue of Baltic herring, stored under frozen conditions (temperature of $-10,-18$, and $-25^{\circ} \mathrm{C}$, time: 24 weeks)

\begin{tabular}{|c|c|c|c|c|}
\hline Temperature of & \multicolumn{2}{|c|}{$-18^{\circ} \mathrm{C}$} & \multicolumn{2}{c|}{$-25^{\circ} \mathrm{C}$} \\
\cline { 2 - 5 } frozen storage & $\mathrm{t}$ & $\mathrm{p}$ & $\mathrm{t}$ & $\mathrm{p}$ \\
\hline$-10^{\circ} \mathrm{C}$ & -1.675 & 0.120 & -6.419 & $3.31 \mathrm{E}-5^{*}$ \\
$-18^{\circ} \mathrm{C}$ & & & -4.540 & $6.78 \mathrm{E}-4^{*}$ \\
\hline
\end{tabular}

* Statistically significant difference.
Effect of salt on the activity of lipoxygenase of the muscle tissue and the roe of Baltic herring was determined based on fish caught in May 1997. The terminal content of salt in these raw materials was $9.80,12.3$, and $18.3 \%$ for weak-, medium- and strong salting, respectively. The activity of analysed enzyme in the muscle tissue and roe of fish taken for salting was quite similar, although, during salting a variable dynamics of the activity was observed (Figs. 3, 4). Salt lowered the lipoxygenase activity of the muscles of herring. The inhibiting action of salt was the stronger the higher was its concentration. Considering the entire salting period, the enzyme activity in the muscles lowered itself to $84.0,69.3$, and $51.8 \%$, respectively for weakly-, medium-, and strongly salted herring. Statistical analysis did not show, however, any significant differences, between these results (Table 3). 


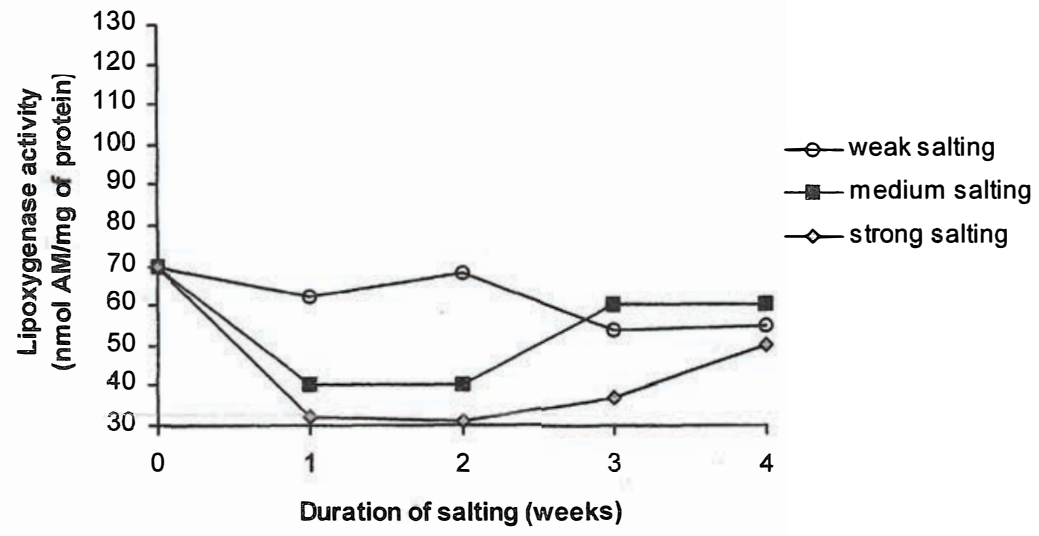

Fig. 3. Effect of the salting process on the activity of lipoxygenase of the muscle tissue of Baltic herring

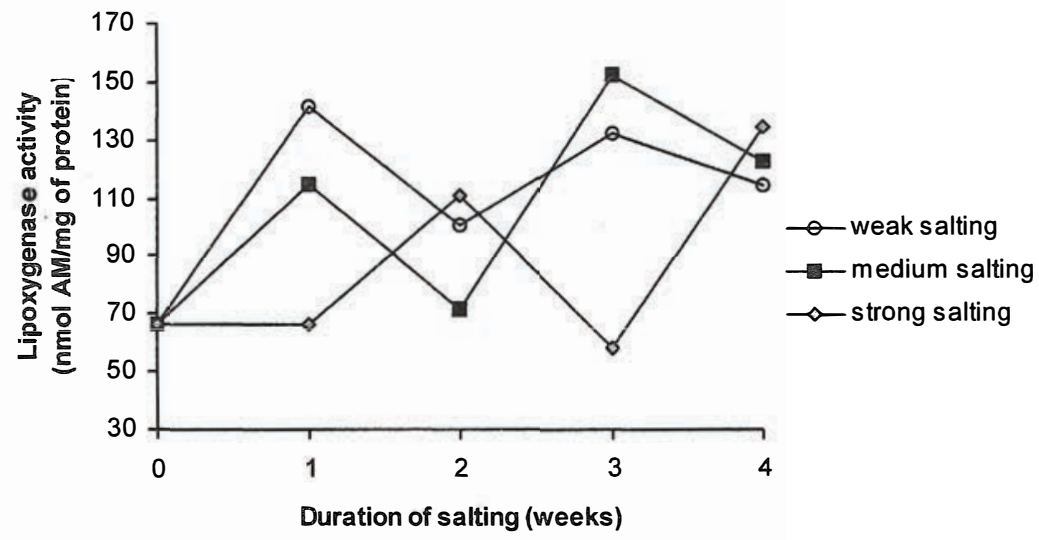

Fig. 4. Effect of the salting process on the activity of lipoxygenase of the roe of Baltic herring 
Table 3

Student t-test values for lipoxygenase activity of the muscle tissue and roe of Baltic herring, subjected to salting process

\begin{tabular}{|l|l|c|c|c|c|}
\hline \multirow{2}{*}{ Sample } & \multirow{2}{*}{ Way of salting } & \multicolumn{2}{|c|}{ Medium } & \multicolumn{2}{c|}{ Strong } \\
\cline { 3 - 6 } & & $\mathrm{t}$ & $\mathrm{p}$ & $\mathrm{t}$ & $\mathrm{p}$ \\
\hline Muscle tis- & Weak & 1.173 & 0.306 & 2.674 & 0.056 \\
sue & Medium & & & 2.620 & 0.059 \\
\hline \multirow{2}{*}{ Roe } & Weak & 0.607 & 0.577 & 1.084 & 0.339 \\
& Medium & & & 0.753 & 0.494 \\
\hline
\end{tabular}

In the case of lipoxygenase of the roe of herring, an increase of its activity in the process of salting was observed, most of all the weak one, in lesser extent-medium one and the least-the strong one (Fig. 4). Ac-

tivity of the entire period of roe salting was respectively on average: 184.4, 174.2, and $139.5 \%$ of the initial activity. Statistical analysis did not reveal, however, any significant differences in the activity of lipoxygenase of roe of herring containing variable contents of salt (Table 3). It is probably caused by extensive fluctuations of the activity of this enzyme in respective periods of the roe salting process.

Lipoxygenase of the roe of Baltic herring, in the course of the monitored period of weak-, medium-, and strong salting, exhibited much more higher activity and dynamics of its changes, than lipoxygenase of the muscle tissue of these fish. Sodium chloride in the concentration from 9.80 to $18.30 \%$ activated lipoxygenase in the roe of herring, whereas in the muscle tissue of these fish it inhibited its action. The observed effect of sodium chloride on lipoxygenases of the analysed raw materials indicates variable protein structures and/or molecular weight of these enzymes, dealing with different functions of the muscle system and gonads when fish are alive.

In this paper was carried out also analysis of effects of selected inorganic salts on the activity of lipoxygenase of the muscle tissue of Baltic herring caught in February 1999. Enzyme extracts were supplemented with sodium chloride, while the remaining salts were selected only because of their possible presence in the table salt or in the sea water, which has been used for chilling fishes on high-sea fishing vessels. The present study revealed that $\mathrm{NaCl}$ inhibited lipoxygenase in all tested concentrations (Figs. 5, 6). Activity of the enzyme decreased by some 15-35 percentage points and 35-65 percentage points, respectively for $\mathrm{NaCl}$ concentrations of $1-10 \%$ and $11-20 \%$. On the other hand $\mathrm{NaCl}$ in concentration of $26.4 \%$ (saturated solution) reduced activity of the enzyme over 70 percentage points.

The remaining salts differed from $\mathrm{NaCl}$ with the dynamics of lipoxygenase inhibition (Fig. 6). The enzyme activity was lowered by a maximum of $50 \%$ for $\mathrm{CaCl}_{2}(1.50 \%)$, $\mathrm{MgCl}_{2}(0.50 \%)$, and $\mathrm{KCl}$ (3.0\%). Some concentrations of $\mathrm{CaCl}_{2}(0.50,3.50,4.0,5.0 \%)$ exhibited catalytic action on the enzyme. 


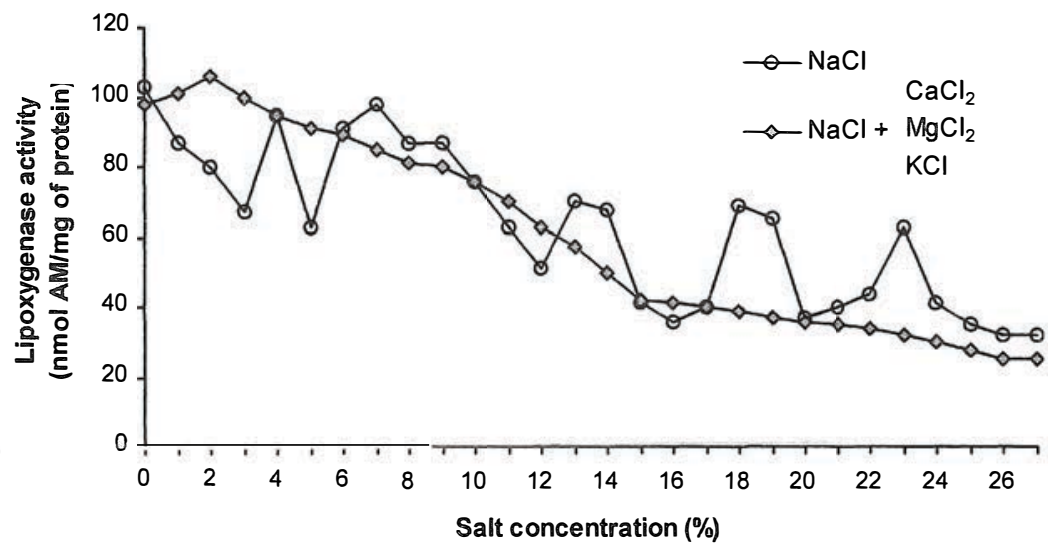

Fig. 5. Effect of $\mathrm{NaCl}$ concentration and its mixtures with chlorides of other metals on the activity of lipoxygenase of the muscle tissue of Baltic herring

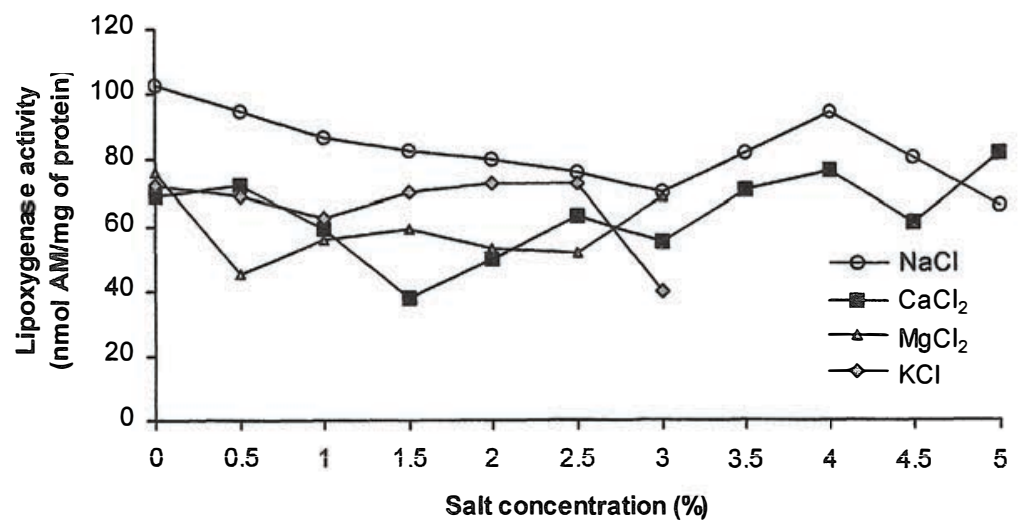

Fig. 6. Effect of inorganic salts on the activity of lipoxygenase of the muscle tissue of Baltic herring

Statistical analysis of the results revealed differences in the enzyme activity, between the sample containing $\mathrm{NaCl}$ and $\mathrm{CaCl}_{2}$ and between the sample containing $\mathrm{MgCl}_{2}$ and the one containing $\mathrm{KCl}$ (Table 4). The salt mixture in the concentration up to $2.0 \%$ catalysed lipoxygenase, while above this concentration it inhibited this enzyme with particularly high rate, up to the concentration of $15 \%$. In the concentration of $15-26.4 \%$ the pace of inhibition was much lower. The decrease in the lipoxygenase activity was respectively some 60 and 80 percentage points in relation to the value stated for the sample devoid of salt. Addition of the salt mixture up to some $5.0 \%$ showed lower inhibitory efficiency, than each of 
Table 4 the salts used separately. On the other

Student t-test values for lipoxygenase activity of the muscle tissue of Baltic herring in the presence of $\mathrm{NaCl}$ and $\mathrm{CaCl}_{2}$, and $\mathrm{MgCl}_{2}$ and $\mathrm{KCl}$

\begin{tabular}{|c|c|c|}
\hline \multirow{2}{*}{ Kind of salt } & \multicolumn{2}{|c|}{$\mathrm{CaCl}_{2}$} \\
\cline { 2 - 3 } & $\mathrm{t}$ & $\mathrm{p}$ \\
\hline $\mathrm{NaCl}$ & 4.379 & $1.38 \mathrm{E}-3^{*}$ \\
\hline \multirow{2}{*}{$\mathrm{KCl}$} \\
\cline { 2 - 3 } & $\mathrm{t}$ & $\mathrm{p}$ \\
\hline $\mathrm{MgCl}_{2}$ & -1.039 & 0.339 \\
\hline
\end{tabular}

*Statistically significant difference.

Table 5

Student t-test values for lipoxygenase activity of the muscle tissue of Baltic herring in the presence of $\mathrm{NaCl}$ and its mixture with chlorides of other metals

\begin{tabular}{|c|c|c|}
\hline \multirow{2}{*}{ Kind of salt } & \multicolumn{2}{|c|}{$\mathrm{NaCl}+\mathrm{CaCl}_{2}+\mathrm{MgCl}_{2}+\mathrm{KCl}$} \\
\cline { 2 - 3 } & $\mathrm{t}$ & $\mathrm{p}$ \\
\hline $\mathrm{NaCl}$ & 1.018 & 0.318 \\
\hline
\end{tabular}
hand, the action of higher concentrations of sodium chloride (above 10\%) in a mixture with the remaining chlorides was similar to the action of $\mathrm{NaCl}$ alone in the same concentrations (Fig. 5). Statistical analysis did not revealed significant difference, between activities of lipoxygenase from the muscle tissue of Baltic herring in the presence of $\mathrm{NaCl}$ on the enzyme activity in the presence of $\mathrm{NaCl}$ mixture with chlorides of other metals (Table 5).

In general it was demonstrated that $\mathrm{NaCl}$ showed the lowest effectiveness in inhibiting lipoxygenase of the muscle tissue of Baltic herring, compared to all other individually used salts, but it was more effective than its mixture with $\mathrm{CaCl}_{2}$, $\mathrm{MgCl}_{2}$, and $\mathrm{KCl}$.

\section{DISCUSSION}

In the present study, a high activity of lipoxygenase of the muscle tissue of Baltic herring was stated at freezing temperatures $\left(-10,-18\right.$, and $\left.-25^{\circ} \mathrm{C}\right)$. The enzyme activity at $-25^{\circ} \mathrm{C}$ was retained in higher extent than it was at $-10^{\circ} \mathrm{C}$. Eun et al. (1994) observed also a reversibly proportional relation between lipoxygenase activity and the temperature of frozen storage of fish raw materials. According to above authors activity of the lipid-oxidising enzymatic system of the muscle tissue of a catfish was the highest at $-70^{\circ} \mathrm{C}$, and the lowest at $-10^{\circ} \mathrm{C}$. Zhang et al. (1992) studying the activity of such enzymatic system of the skin of Plecoglossus altivelis concluded that it retained the highest activity during storage at $-80^{\circ} \mathrm{C}$, than at $-50^{\circ} \mathrm{C}$. Lipoxygenase isolated from beef kept at $-20^{\circ} \mathrm{C}$ turned out being the most effective catalyst of oxidation-reduction processes, than that from beef kept at $4{ }^{\circ} \mathrm{C}$ (Rhee et al. 1984).

Activity of lipoxygenases of fish raw materials after frozen storage is dependent on the degree of structural changes of proteins of these enzymes caused by crystallisation effects of tissue liquid and also influence of lipid oxidation products (Apgar and Hultin 1982; Hultin 1994). According to Eun et al. (1994) the lowest activity of lipoxygenase of the 
muscles of a catfish during its storage at $-10^{\circ} \mathrm{C}$ than in $-40^{\circ} \mathrm{C}$ can be associated with their more extensive structural changes in higher freezing temperatures. On the other hand, freezing raw materials in the latter is a reason for deepening of denaturation changes of proteins during thawing. An important factor determining lipoxygenase activity is the duration of frozen storage. Eun et al. (1994) observed a substantial lowering of activity of this enzyme in the muscle tissue of catfish along with extension of the storage time at $-10^{\circ} \mathrm{C}$. On the other hand, at $-40^{\circ} \mathrm{C}$ activity of the enzyme was retained at higher extent. Along with extension of the frozen storage time of the catfish filets, grew also differences in the lipoxygenase activity at both temperatures.

In the present work, demonstrated inhibition effect on lipoxygenase of the muscle tissue and catalysing effect on lipoxygenase of the roe of Baltic herring (entire specimens) by salt concentrations from 9.80 to $18.30 \%$ during 4 -week salting at $4{ }^{\circ} \mathrm{C}$. Inhibiting action of $\mathrm{NaCl}$ and its mixture with other chlorides, in relation to the enzyme of the muscle tissue of herring were confirmed in a model system. According to Osinchak et al. (1992) NaCl under concentration of $43.0 \mathrm{mM}$ stimulated the enzymatic system of the muscle tissue of mackerel in the processes of lipid oxidation. $\mathrm{CaCl}_{2}$ and $\mathrm{SrCl}_{2}$ under concentration of $43.0 \mathrm{mM}$ were characterised by the effectiveness similar to $\mathrm{NaCl}$ at the same concentration, while the remaining chlorides $(\mathrm{KCl}, \mathrm{LiCl}-45.0 \mathrm{mM})$ and sulphides $\left(\mathrm{Na}_{2} \mathrm{SO}_{4}, \mathrm{~K}_{2} \mathrm{SO}_{4}, \mathrm{LiSO}_{4}\right.$ $143.0 \mathrm{mM}$ ) were less effective. The present study demonstrated that the mixture of $\mathrm{NaCl}$ with calcium chloride, potassium chloride, and magnesium chloride, of the joint concentration of $2 \%$ catalysed lipoxygenase of the muscle tissue of Baltic herring, and each of the salts applied separately in this concentration, inhibited this enzyme.

According to Hultin et al. (1990) catalysing activity of sodium chloride is probably associated with chlorine ions, which are able to bind to iron ions (Osinchak et al. 1992). On the other hand, cations can also affect catalytic activity of $\mathrm{NaCl}$, particularly bivalent cations showed higher ability to stimulate enzymatic oxidation, than monovalent ions. Activity of cations and anions is probably associated with the substrate, but not with watersoluble components of the enzyme extract. Changes in the bimolecular structure of lipids, caused by salts, can be a reason for their better contact with lipoxygenase (Osinchak et al. 1992). Effect of catalysing oxidative enzymatic changes by $\mathrm{NaCl}$ can be, however, visible with lower concentrations of this salts. Also, salt ions can in a variable way affect other systems contributing to a complicated mechanism of lipid oxidation. Effect of salts on the enzymatic system oxidising lipids, certainly depends on the technological conditions of the salting process and the fish species, and also the tissue-muscle tissue or hard roe, that, as show present investigations contain lipoxygenases having different sensitivity to $\mathrm{NaCl}$ and also to freezing temperatures. Presumably result from different functions of the muscles and roe in life fish organisms. 


\section{CONCLUSIONS}

1. Lipoxygenase activity of the muscle tissue and roe of Baltic herring stored for 6 months at $-25^{\circ} \mathrm{C}$ reached the levels of $78.2 \%$ and $70.0 \%$, respectively, of the initial activity measured before freezing and the storage of fish.

2. Activity of the enzyme extracted from the muscle tissue of herring and kept in a buffer solution at $-10,-18$, and $-25^{\circ} \mathrm{C}$ decreased in reversed proportion to the storage temperature.

3. $\mathrm{NaCl}$ in concentrations from ca 10.0 to $18.0 \%$ in the environments of natural muscle tissue and roe catalysed lipoxygenase of the roe, while it inhibited lipoxygenase of the muscle tissue of Baltic herring, in direct proportion to the concentration used.

4. Activity of the enzyme of the muscle tissue of herring in the model system with buffer was lowered proportionally to the increase of sodium chloride concentration from 1.0 to 26.4\%. Inhibitory effectiveness of $\mathrm{NaCl}$ was the lowest among all separately used salts in concentrations from 0.5 to $5.0 \%$, but it was more effective, than its mixture with $\mathrm{CaCl}_{2}, \mathrm{MgCl}_{2}$, and $\mathrm{KCl}$ in concentrations from 2.0 to $26.4 \%$.

5. Oxidation of lipids in the muscle tissue and roe of Baltic herring during frozen storage as well as the salting process runs also on enzymatic way.

\section{REFERENCES}

Andersen A.A. T.C. Fletcher, G.M. Smith, 1981: Prostaglandin biosynthesis in the skin of plaice. Pleuronectes platessa L. Comp. Biochem. Physiol., 70 C: 195-199.

Apgar M.E. H.O. Hultin, 1982: Lipid peroxidation in fish muscle microsomes in frozen state. Cryobiology, 19: 154-162.

Decker E.A., M.C. Erickson, H.O. Hultin, 1988: Enzymic lipid oxidative activity of sarcoplasmic reticulum in several species of Northwest Atlantic fish. Comp. Biochem. Biophys., 91 B: 7-9.

Decker E.A, C.H. Huang, J.E. Osinchak, H.O.Hultin, 1989: Iron and copper: Role in enzymic lipids oxidation of fish sarcoplasmic reticulum at in situ concentrations. J. Food Biochem., 13: 179-186.

Decker E.A., H.O. Hultin, 1990: Factors influencing the catalysis of lipid oxidation by the soluble fraction of mackerel muscle. J. Food Sci., 55: 997.

Eun J.B., J.A. Boyle, J.O. Hearnsberger, 1994: Lipid peroxidation and chemical changes in catfish (Ictalurus punctatus) muscle microsomes during frozen storage. J. Food Sci., 59: 251255.

Eun J.B., J.O. Hearnsberger, J.A. Boyle, 1992: Enzymic lipid peroxidation system in channel catfish (Ictalurus punctatus) muscle microsomes. J. Aquatic Food Product Technology, 1, 3/4: 91-107. 
Gardner H.W., 1980: Lipid enzymes: lipases, lipoxygenases and hydroperoxidases. In: Autoxidation in food and biological systems [Simic M.G.S., M. Karel, (eds.)]. Plenum Press, New York: 447-504.

German J.B., G. Bruckner, J.E. Kinsella, 1986: Lipoxygenases in trout gill tissue affecting on arachidonic, eicosapentaenoic and docosahexaenoic acids. Biochim. Biophys. Acta, 875: 1220.

German J.B., R.K. Creveling, 1990: Identification and characterization of a 15-lipoxygenase from fish gills. J. Agric. Food Chem., 38: 2144-2147.

German J.B, M.L. Hu, 1990: Oxidant stress inhibits the endogenous production of lipoxygenase metabolites in rat lungs and fish gills. Free Rad. Biol. Med., 8: 441-448.

German J.B., J.E. Kinsella, 1985: Lipid oxidation in fish tissue. Enzymatic initiation via lipoxygenase. J. Agric. Food Chem., 33: 680-683.

German J.B., J.E. Kinsella, 1986: Hydroperoxide metabolism in trout gill tissue: effect of glutathione on lipoxygenase products generated from arachidonic acid and docosahexaenoic acid. Biochim. Biophys. Acta, 879: 378-387.

Grun I.U., W.E. Barbeau, 1995: Lipoxygenase activity in menhaden gill tissue and its effect on odor of n-3 fatty acid ester concentrates. J. Food Biochem., 18: 199-212.

Harris P., J. Tall, 1994: Substrate specificity of mackerel flesh lipopolygenase. J. Food Sci., 59: 504-506, 516.

Hsieh R.J., J.B. German., J.E. Kinsella, 1988: Lipoxygenase in fish tissue: Some properties iof the 12-lipoxygenase from trout gill. J. Agric. Food Chem., 36: 680-685.

Hsieh R.I., J.E. Kinsella, 1989: Lipoxygenase generation of specific volatile flavor: Carbonyl compounds in fish tissue. J. Agric. Food Chem., 37: 279-286.

Hsu H.H., B.S. Pan, 1996: Effects of protector and hydroxyapatite partial purification on stability of lipoxygenase from gray mullet gill. J. Agric. Food Chem., 44: 741-745.

Huang C.H., M.H. Huang, A.H. Lee, 1998: Characteristics of lipid peroxidation in sarcoplasmic reticulum of tilapia. Food Sci.,25:104-108.

Hultin H.O., 1988: Potential lipid oxidation problems in fatty fish processing. In: Fatty fish utilization: Upgrading from feed to food. Proceedings of a National Technical Conference [Davis N., (ed.)]. UNC Sea Grant College Program, Raleigh, N.C.:185-223.

Hultin H.O., 1992: Biochemical deterioration of fish muscle. In: Quality assurance in the fish industry [Huss H.H., M. Jakobsen, J. Liston, (eds.)]: 125-138.

Hultin H.O., 1994: Oxidation of lipids in seafoods. In: Seafoods: Chemistry, Processing Technology and Quality [Shahidi F., J.R. Botta (eds.)]. Blackie Academic and Professional, Glasgow: $49-74$.

Hultin H.O., E.A. Decker, S.D. Kelleher, J.E. Osinchak, 1990: Control of lipid oxidation process in minced fatty fish. In: Seafood Science and Technology, Canada 13-16 May 1990: 93100.

Hultin H.O., R.E. McDonald, S.D. Kelleher, 1982: Lipid oxidation in fish muscle microsomes. In: Chemistry and biochemistry of marine food products [Martin R.E., G.J. Flick, C.E. Hebard, D.R. Ward (eds.)]. The AVI Publishing Co., Westport, CT: 1-11.

Josephson D.B., R.C. Lindsay, 1986: Enzymatic generation of volatile aroma from fresh fish. In: Biogeneration of aroma [Croteau T.H., (ed.)]. American Chemical Society, Washington DC: 201-221.

Linko R.R., 1967: Fatty acids and other components of Baltic herring flesh lipids. Ann. Univ. Turku, Ser. A, 101: 7-121.

McDonald R.E., H.O. Hultin, 1987: Some characteristics of the enzymic lipid peroxidation systems in the microsomal fraction of flounder muscle. J. Food Sci., 52: 15-21, 27.

McDonald R.E., S.D. Kelleher, H.O. Hultin, 1979: Membrane lipid oxidation in a microsomal fraction of red hake muscle. J. Food Biochem., 3: 125-134. 
Mohri S., S.Y. Cho, Y. Endo, K. Fujimoto, 1990: Lipoxygenase activity in sardine skin. Agric. Biol. Chem., 54: 1889-1891.

Mohri S., S.Y. Cho, Y. Endo, K. Fujimoto, 1992: Linoleate 13(S)-lipoxygenase in sardine skin. J. Agric. Food Chem., 40: 573-576.

Osinchak J.E., H.O. Hultin, O.T. Zaicek, S.D. Kelleher, C.H. Huang, 1992: Effect of $\mathrm{NaCl}$ on catalysis of lipid oxidation by the soluble fraction of fish muscle. Free Rad. Biol. Med., 12: $35-41$.

Rhee K.S., T.R. Dtson, G.C. Smith, 1984: Enzymic lipid peroxidation in microsomal fractions from beef skeletal muscle. J. Food Sci., 49: 675.

Schmedes A., G. Holmer, 1989: A new thiobarbituric acid (TBA) method for determining free malonodialdehyde (MDA) and hydroperoxides selectively as a measure of lipid peroxidation. J. Am. Oil Chem. Soc. Sci., 66: 813-817.

Slabyj B.M., H.O. Hultin, 1982: Lipid peroxidation by microsomal fractions isolated from light and dark muscles of herring (Clupea harengus). J. Food Sci., 47: 1395-1398.

Slabyj B.M., H.O. Hultin, 1984: Oxidation of a lipid emulsion by a peroxidizing microsomal fraction from herring muscle. J. Food Sci., 49: 1392-1393.

Stodolnik L., E. Samson, 2000: Lipoxygenase activity of selected tissues and organs of Baltic herring. Acta Ichthyol. Piscat., 30, 2: 47-57.

Takiguchi A., 1989: Effect of $\mathrm{NaCl}$ on the oxidation and hydrolysis of lipids in salted sardine fillets during storage. Bull. Japan Soc. Sci. Fish., 55: 1649-1654.

Triqui R., G.A. Reineccius, 1995: Flavor development in the ripening of anchovy (Engraulis encrasicholus L.). J. Agric. Food Chem., 43: 453-458.

Wang Y.J., L.A, Miller , P.B. Addis, 1991: Effect of heat inactivation of lipoxygenase on lipid oxidation in lake herring. J. Am. Oil Chem. Soc., 68: 752-757.

Winkler M., G. Pilhofer, J.B. German, 1991: Stereochemical specificity of the n-9 lipoxygenase of fish gill. J. Food Biochem., 15: 437-448.

Yamamoto S., 1992: Mammalian lipoxygenases: molecular structures and functions. Biochim. Biophys. Acta, 1128: 117-131.

Zhang C.H., T. Hirano, T. Suzuki, T. Shirai, 1992: Enzymatically generated specific volatile compounds in ayu tissues. Bull. Japan Soc. Sci. Fish., 58: 559-565. 
Edyta SAMSON, Ludmiła STODOLNIK

\section{WPŁYW ZAMRAŻANIA ORAZ SOLENIA NA AKTYWNOŚĆ LIPOOKSYGENAZY TKANKI MIESŚNIOWEJ I IKRY ŚLEDZI BAŁTYCKICH}

\section{STRESZCZENIE}

W badaniach analizowano zmiany aktywności lipooksygenazy tkanki mięśniowej i ikry śledzi $\mathrm{w}$ czasie przechowywania $\mathrm{w}$ temperaturze $-25^{\circ} \mathrm{C}$ w okresie 6 miesięcy. Określano także wpływ na jej aktywność solenia słabego, średniego i mocnego.

Wyniki badań wykazały, że zamrażalnicze przechowywanie śledzi całych w temperaturze $-25^{\circ} \mathrm{C}$ powodowało obniżenie aktywności tego enzymu w tkance mięśniowej do $78,2 \%$, a w ikrze ryb do $70,0 \%$.

Aktywność enzymu wyekstrahowanego z tkanki mięśniowej śledzi i przechowywanego $\mathrm{w}$ roztworze buforowym $\mathrm{w}$ temperaturze $-10,-18 \mathrm{i}-25^{\circ} \mathrm{C}$ ulegała tym większemu obniżeniu im wyższa była temperatura przechowywania.

Solenie śledzi do końcowej zawartości soli od 9,8 do 18,3\% prowadziło do obniżenia aktywności lipooksygenazy tkanki mięśniowej proporcjonalnie do stężenia soli. Lipooksygenaza ikry była katalizowana podczas solenia, ale w większym stopniu słabego $(9,8 \%)$ niż średniego $(12,3 \%)$ oraz mocnego $(18,3 \%)$.

W układzie modelowym w środowisku buforu zawierającego $\mathrm{NaCl}$, aktywność enzymu tkanki mięśniowej śledzi ulegała obniżeniu w miarę zwiększania stężenia soli od 1,0 do 26,4\%. Efektywność inhibitująca $\mathrm{NaCl}$ była najniższa spośród wszystkich indywidualnie zastosowanych soli o stężeniu od 0,5 do $5,0 \%$, ale był on bardziej efektywny niż jego mieszanina $\mathrm{z}$ chlorkiem wapnia, magnezu i potasu w stężeniu od 2,0 do $26,4 \%$.

Received: 10 May 2001

Author's address:

Ludmiła Stodolnik PhD DSc Prof

Department of Refrigeration

Agricultural University of Szczecin

Papieża Pawła VI 3, 71-459 Szczecin, Poland

e-mail: chlodnictwo@tz.ar.szczecin.pl 